\title{
Sistem Informasi Penyewaan Lapangan Bulu Tangkis Berbasis Web Pada GOR Villa Mas Indah Bekasi Utara
}

\author{
Tumbur Togu ${ }^{1}$, Herlawati ${ }^{1, *}$, Adi Muhajirin ${ }^{1}$ \\ * Korespondensi: e-mail: herlawati@dsn.ubharajaya.ac.id
}

\begin{abstract}
${ }^{1}$ Informatika; Universitas Bhayangkara Jakarta Raya; Jl. Raya Perjuangan, Marga Mulya, Bekasi Utara. 17121, +62 $21 \quad$ 88955882;

tumbur.togu16@mhs.ubharajaya.ac.id, herlawati@dsn.ubharajaya.ac.id, adi.muhajirin@dsn.ubharajaya.ac.id.
\end{abstract}

Submitted: 15 Maret 2021

Revised: 7 April 2021

Accepted: 28 April 2021

Published: 25 Mei 2021

\begin{abstract}
Web-Based Badminton Court Rental Information System at GOR Villa Mas Indah, North Bekasi. Badminton GOR Villa Mas Indah is a business brand engaged in sports. However, the information system implemented in the company still tends to have many shortcomings and weaknesses by using a ledger, therefore the company needs a Web-Based Badminton Court Rental Information System Design at GOR Villa Mas Indah Bekasi Utara with the aim of helping in improving the business brand marketing strategy. and maximizing service with the aim of facilitating performance in data processing, changing data, viewing field schedule information, and data stored automatically and safely. The system development method uses Waterfall. Data collection methods are interviews, observation, literature study and questionnaires. The system design uses UML, the system is built using the PHP programming language, with MySQL database and application display using CSS Bootstrap. Testing the system using Blackbox Testing.
\end{abstract}

Keywords: Booking, Information Systems, Rental, Waterfall, Web Based.

\section{Abstrak}

Sistem Informasi Penyewaan Lapangan Bulu Tangkis Berbasis Web Pada GOR Villa Mas Indah Bekasi Utara. GOR Bulu tangkis Villa Mas Indah adalah brand usaha yang bergerak di bidang olahraga. Namun sistem informasi yang di terapkan dalam perusahaan masih cenderung memiliki banyak kekurangan dan kelemahan dengan menggunakan buku besar, oleh karena itu perusahaan perlunya Perancangan Sistem Informasi Penyewaan Lapangan Bulu Tangkis Berbasis Web Pada GOR Villa Mas Indah Bekasi Utara dengan tujuan membantu dalam meningkatkan strategi marketing brand usaha dan memakasimalkan pelayanan dengan tujuan mempermudah kinerja dalam mengolah data, mengubah data, melihat informasi jadwal lapanagan, serta data tersimpan secara otomatis dan aman. Metode pengembangan sistem menggunakan Waterfall. Metode pengumpulan data yaitu Wawancara, Observasi, Studi Pustaka dan Kuesioner. Desain sistem menggunakan UML, sistem di bangun menggunakan bahasa pemograman PHP, dengan basis data MySQL dan tampilan aplikasi menggunkan CSS Bootstrap. Pengujian sistem menggunakan Blackbox Testing.

Kata kunci: Berbasis Web, Booking, Penyewaan, Sistem Informasi, Waterfall. 


\section{Pendahuluan}

Olahraga menjadi salah satu kebutuhan pokok masyarakat sekitar dan ada bisnis yang bergerak dibidang olahraga sangat diminati para pengusaha, dengan latar belakang saat ini manusia hidup pada era 4.0 maka sistem informasi berbasis web sangat membantu dalam meningkatkan strategi marketing brand usaha yang akan diciptakan, maka dari itu website sangat diperlukan untuk memakasimalkan pelayanan yang akan disediakan oleh brand tersebut. GOR Bulu Tangks Villa Mas Indah mempunyai 4 Lapangan yang tersedia untuk disewa pada setiap harinya akan buka pukul 10.00 pagi sampai dengan pukul 23.00 malam dan proses penyewaan masil dikalukan secara manual konsumen harus terlebih dahulu datang ke lokasi GOR Bulu Tangkis Villa Mas Indah dan menanyakan Jadwal yang tersedia lalu pemilik GOR akan melakukan pengecekan Jadwal pada Buku Besar apabila tersedia pelanggan akan menyewa lapangan dan membayar secara tunai dengan harga yang ditentukan oleh pemilik GOR lalu pelanggan akan menerima kwitansi. Pada setiap harinya akan buka selama 13jam pada setiap Lapangan. Jika di total keseluruhan dalam satu bulan akan menghasilkan 390 jam pada setiap Lapangan dan berikut adalah hasil survey pada GOR Bulu Tangkis Villa Mas Indah pada setiap Lapanganya pada bulan November dan Desember di tahun 2020.

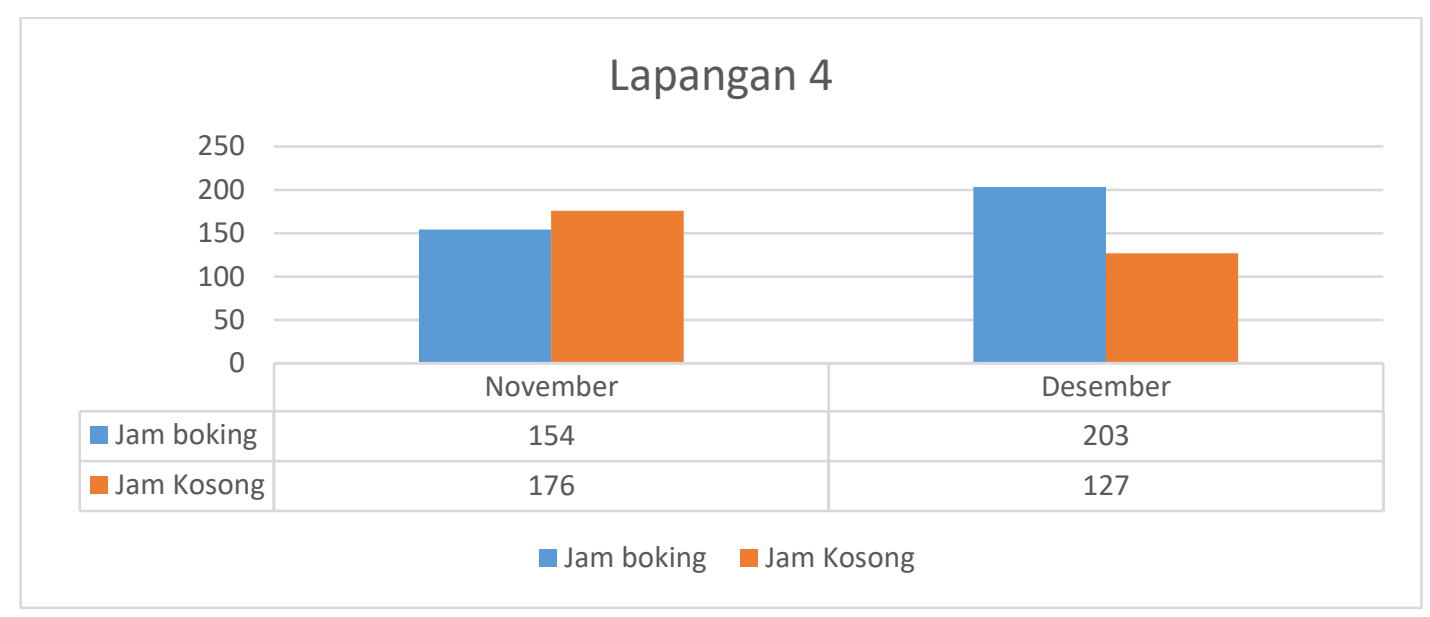

Sumber: GOR Bulu Tangkis Villa Mas Indah (2020)

Gambar 1. Diagram Lapangan 4 Pada Bulan November dan Desember

Pada Gambar 1 terlihat pada Lapangan 4 dapat di hitung total 154 jam yang sudah disewa atau Booking dan terdapat 176 jam yang kosong atau tidak disewa dalam bulan November dan dapat di hitung total 203 jam yang sudah di sewa atau Booking dan terdapat 127 jam yang kosong atau tidak disewa dalam bulan Desemeber.

Berdasarkan hasil survei peneliti mendapatkan poin penting mengenai hasil Penyewaan Lapangannya dan beberapa Konsumen pernah mengalami ketidaksamaan data pembayaran secara tunai saat pemesanan lapangan sehingga Pemilik GOR harus bertanggung jawab atas kesalahan tersebut.

Oleh karena itu perlu dibangun sistem informasi penyewaan lapangan. Sistem informasi akan memudahkan kebutuhan pengolahan transaksi harian akan mendukung organisasi dalam kegiatan strategi menyediakan informasi yang diperlukan dan laporan-laporan untuk 
pengambilan keputusan kepada pihak tertentu (Anggraeni, 2017; Hutahaen, 2015). Sistem informasi merupakan bagian besar dari sistem, yang berupa sekumpulan prosedur saling berkaitan dan terhubung melakukan tugas bersama terdiri atas tiga komponen utama software, hardware, dan brainware (Harianto et al., 2019; Yudhanto \& Prasetyo, 2018), memiliki ciri karakteristik komponen sistem, batasan sistem, lingkungan, penghubung sistem, masukan, keluaran, pengolah dan sasaran (Arief, 2019). Peralatan pendukung sistem diperlukan sebagai model sistem dapat digambarkan menggunakan diagram dan simbol yang menunjukkan fungsinya seperti Unified Modelling Language (Muslihudin \& Oktafianto, 2016), pada penelitian ini digunakan diagram use case diagram, activity diagram, sequence diagram, class diagram.

Sistem informasi dalam penelitian ini membangun sistem informasi penyewaan lapangan berbasis website, sebagai sekumpulan halaman berisi suatu informasi seperti berupa text, gambar, video audio dan animasi disediakan melalui jalur koneksi internet (Robi, 2020), dengan bahasa pemrograman Hypertext Preprocessor (PHP) pertama kali dibuat oleh Rasmus Lerdorf pada 1995 digunakan untuk membuat website dinamis dan menangani antara client side scripting dan server side scripting (Sulisistiono, 2018).

Peneliti memilih sistem penyewaan lapangan berbasis web, karena pelayanan dari usaha olahraga bulu tangkis ini masih menggunakan manual atau secara buku besar, dengan adanya sistem penyewaan berbasis web maka peluang pemasaran semakin luas dan konsumen tidak perlu lagi datang ke lokasi untuk pengecekan Jadwal. Sehingga lebih banyak menarik pelanggan dan mengurangi kesalahan data Konsumen terhadap Pemilik GOR Bulu Tangkis.

\section{Metode Penelitian}

Kronologis penelitian, mulai dari desain penelitian, prosedur berbentuk algoritma atau pseudocode untuk menguji data harus didukung referensi, sehingga diterima secara ilmiah (Herlawati et al., 2018).

Peneliti memilih waterfall karena model yang sederhana dengan sistem linear keluaran tahap sebelumnya menjadi masukan tahap berikutnya. Adapun berikut ini penjelasan masingmasing tahap pengembangan model Waterfall dari lima aktivitas yaitu requirements, design sytem, coding \& testing, transition phase, operation \& maintanance (Pressman \& Maxim, 2015)

Requirements, analisis terhadap kebutuhan sistem bisa melakukan wawancara atau study literatur, mengumpulkan informasi sebanyak-banyaknya dari user sehingga akan tercipta sistem yang bisa melakukan tugas-tugas yang diinginkan oleh user tersebut. Design system, model pembuatan struktur data, arsitektur perangkat lunak, representasi antarmuka dan prosedur pengkodean. Di tahap ini menjabarkan model apa yang telah dianalisis sebelumnya, agar diimplementasikan oleh peneliti menjadi program. Coding \& testing, pada tahap pembuatan pengkodean ini desain yang telah dibentuk kemudian di terjemahkan ke dalam program. Transition phase, tahap final dalam pembuatan sistem maka sudah dapat digunakan oleh user. Pemeliharaan (Operation \& Maintanance) sistem yang dibuat ketika disampaikan kepada pelanggan akan mengalami perubahan karena perangkat lunak harus menyesuaikan dengan 
lingkungan baru, atau karena perkembangan fungsional. Oleh karena itu perlu dilakukannya pengujian perangkat lunak, pengujian dengan metode Black Box dapat dipilih karena berfokus pada spesifikasi fungsional untuk mendefinisikan kumpulan kondisi dan melakukan pengujian pada spesifikasi fungsional program (Mustaqbal et al., 2015). Pada gambar 1 merupakan tahapan penelitian yang dilakukan dalam membangun sistem informasi penyewaan lapangan.

\begin{tabular}{|c|c|c|c|}
\hline \multicolumn{4}{|c|}{ Identifikasi Masalah } \\
\hline \multicolumn{4}{|c|}{$\begin{array}{l}\text { Berdasarkan Latar belakang dapat diidentifikasikan permasalahan yang akan di selesaikan } \\
\text { yaitu: } \\
\text { 1. Proses dalam penyewaan Lapangan masih dilakukan secara manual } \\
\text { 2. Tidak samanya data pembayaran } \\
\text { 3. Pembayaran atau Pelunasan masih dilakukan secara tunai }\end{array}$} \\
\hline \multicolumn{4}{|c|}{ Rumusan Masalah } \\
\hline \multicolumn{4}{|c|}{$\begin{array}{l}\text { Berdasarkan Latar belakang dapat diidentifikasikan permasalahan yang akan di selesaikan } \\
\text { yaitu: } \\
\text { 1. Proses dalam penyewaan Lapangan masih dilakukan secara manual } \\
\text { 2. Tidak samanya data pembayaran } \\
\text { 3. Pembayaran atau Pelunasan masih dilakukan secara tunai }\end{array}$} \\
\hline \multicolumn{4}{|c|}{ Pengembangan Metode } \\
\hline \begin{tabular}{|c|} 
Analisis: \\
Wawancara, \\
Observasi dan Studi \\
Pustaka
\end{tabular} & $\begin{array}{l}\text { Design : } \\
\text { UML (Unified Modeling } \\
\text { Language) }\end{array}$ & $\begin{array}{c}\text { Pengkodean : } \\
\text { PHP, MySQL, dan CSS } \\
\text { Bootstrap }\end{array}$ & $\begin{array}{l}\text { Testing: } \\
\text { Black Box }\end{array}$ \\
\hline \multicolumn{4}{|c|}{ Hasil } \\
\hline \multicolumn{4}{|c|}{$\begin{array}{c}\text { SISTEM } \\
\text { INFORMASI PENYEWAAN } \\
\text { LAPANGAN BULU TANGKIS BERBASIS PADA GOR VILLA MAS } \\
\text { INDAH BEKASI UTARA }\end{array}$} \\
\hline
\end{tabular}

Sumber: Hasil Penelitian (2021)

Gambar 1. Kerangka Berfikir Penelitian

\section{Hasil dan Pembahasan}

\subsection{Analisa Kebutuhan Sistem}

Analisis kebutuhan berguna untuk menentukan rancangan sistem yang akan dibangun sesuai dengan permasalahan yang ditemukan di GOR Villa Mas Indah Bekasi Utara di dalam sistem berjalan, kemudian dirubah dengan sistem yang baru penyewaan berbasis website.

\subsection{Use Case Diagram}

Pada sistem yang dirancang, dapat digunakan oleh dua Aktor yaitu Admin sebagai pengelola dan pelanggan sebagai penyewa. Dalam use case gambar 2 terlihat apa yang dapat 
dilakukan oleh aktor terhadap sistem penyewaan lapangan dengan relation sebagai penunjuk antar use case.

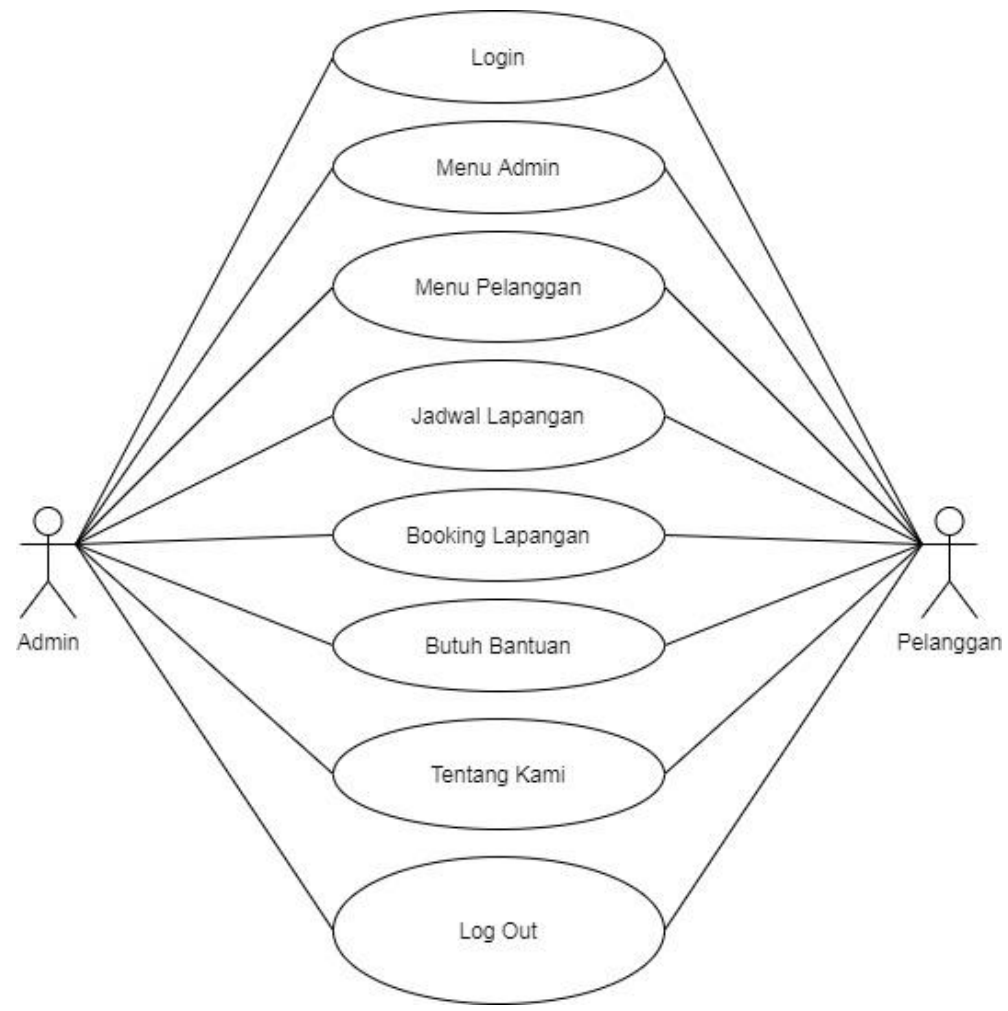

Sumber: Hasil Penelitian (2021)

Gambar 2. Use Case Diagaram

Berdasarkan gambar 2, dapat dideskripsikan bagaimana aktor melakukan interaksi terhadap sistem seperti penjelasan pada tabel 1.

Tabel 1. Deskripsi Use Case

\begin{tabular}{|c|c|c|c|}
\hline No. & Nama Use Case & Deskripsi & Aktor \\
\hline 1 & Register / Login & $\begin{array}{l}\text { Use case menggambarkan mengisi username } \\
\text { dan password untuk dapat mengakses, pengguna } \\
\text { admin dan pelanggan dalam melakukan login } \\
\text { sesuai dengan hak akses masing - masing }\end{array}$ & Pelanggan/Admin \\
\hline 2 & Jadwal Lapangan & $\begin{array}{l}\text { Use Case menggambarkan admin dapat } \\
\text { mengelola jadwal disetiap lapang, tanggal dan } \\
\text { waktu yang tersedia }\end{array}$ & Admin \\
\hline 3 & Jadwal Lapangan & $\begin{array}{l}\text { Use Case menggambarkan user dapat melihat } \\
\text { jadwal disetiap lapang, tanggal dan waktu yang } \\
\text { tersedia }\end{array}$ & Pelanggan \\
\hline 4 & Booking Lapangan & $\begin{array}{l}\text { Use Case menggambarkan admin dapat } \\
\text { mengelola yaitu menambah, mengubah dan } \\
\text { menghapus pada Sub menu Booking dan Riwayat } \\
\text { Booking }\end{array}$ & Admin \\
\hline 5 & Booking Lapangan & $\begin{array}{l}\text { Use Case menggambarkan user dapat memesan } \\
\text { lapangan dengan mengisi data memilih lapangan, } \\
\text { memtukan durasi, tanggal dan waktu dan sub } \\
\text { menu Riwayat Booking untuk menntukan } \\
\text { Pembayaran dan melakukan konfirmasi } \\
\text { pembayaran }\end{array}$ & Pelanggan \\
\hline
\end{tabular}




\subsection{Activity Diagram}

Menggambarkan aliran aktivitas dalam sistem penyewaan lapangan, pada gambar 3 terlihat aliran aktivitas yang dapat dilakukan oleh sistem dalam berinteraksi dengan aktor.

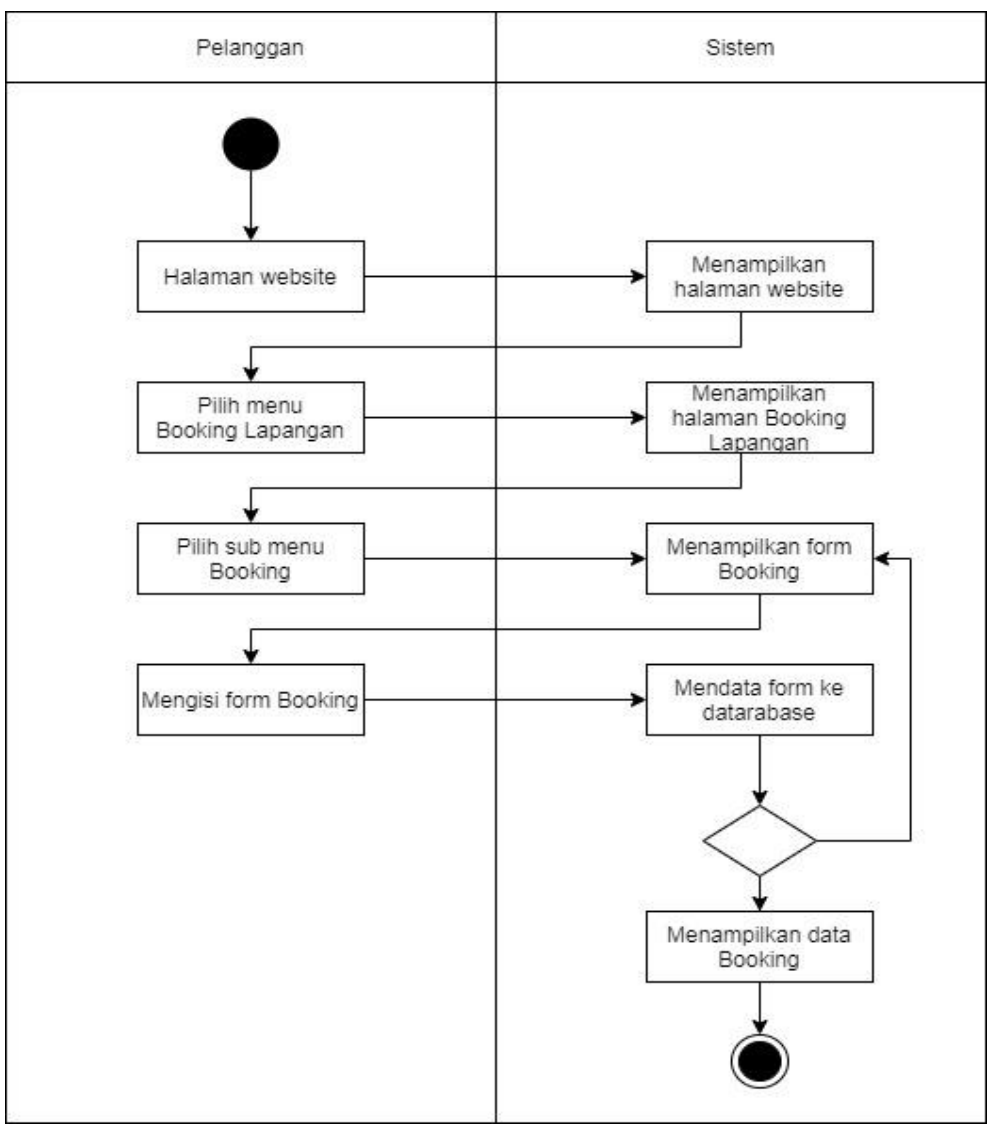

Sumber: Hasil Penelitian (2021)

Gambar 3. Acitivity Diagram Booking Lapangan

Pada gambar 3 pelanggan melakukan aktivitas pemesanan lapangan di sub menu Booking pada menu Booking Lapangan, sebagai berikut (a) Pada halaman utama pengguna pelanggan memilih menu Booking Lapangan, (b) Sistem menampilkan halaman Booking Lapangan, (c) Pelanggan memilih Sub Menu Booking untuk melakukan penyewaan lapangan, (d) Sistem akan menampilkan form yang harus di isi oleh pelanggan untuk menyewa lapangan, (e) Sistem akan mendata ke database jika waktu dan tanggal tidak tersedia sistem akan mengarahkan ke Halaman pengisian form dan jika tanggal dan waktu tersedia akan menampilkan dara pemesan.

Pada gambar 4 Admin melakukan aktivitas mengelola data riwayat, sebagai berikut (a) Pada halaman utama pengguna admin memilih menu Booking Lapangan, (b) Sistem akan menampilkan halaman Booking Lapangan, (c) Admin memilih sub menu Riwayat Booking yang ada dalam Menu Booking Lapangan, (d) Sistem akan menampilkan daftar riwayat Booking, (e) Pengguna admin dapat mengelola yaitu menambah, mengubah, menghapus data riwayat Booking. 


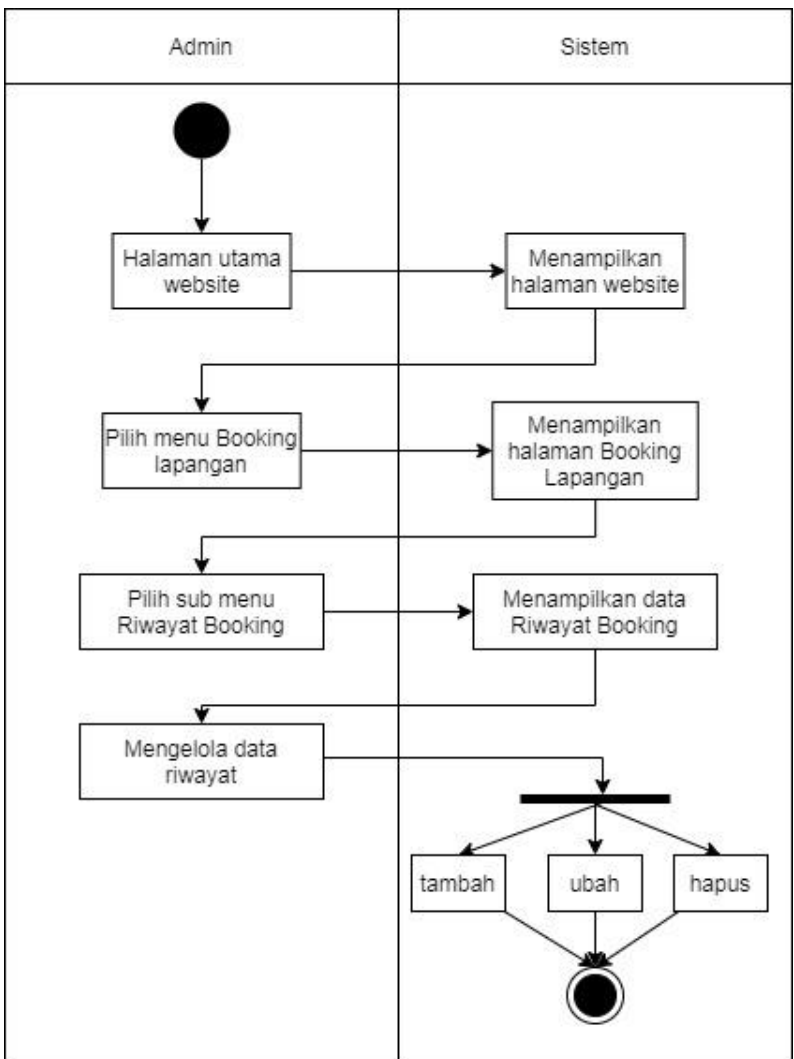

Sumber: Hasil Penelitian (2021)

Gambar 4. Acitivity Diagram Riwayat Booking

\subsection{Sequence Diagram}

Digunakan pada suatu proses interaksi objek disusun dalam suatu kejadian. Sequence diagram. Gambar 5 merupakan kejadian yang dilakukan oleh pelanggan ketika melakukan Booking.

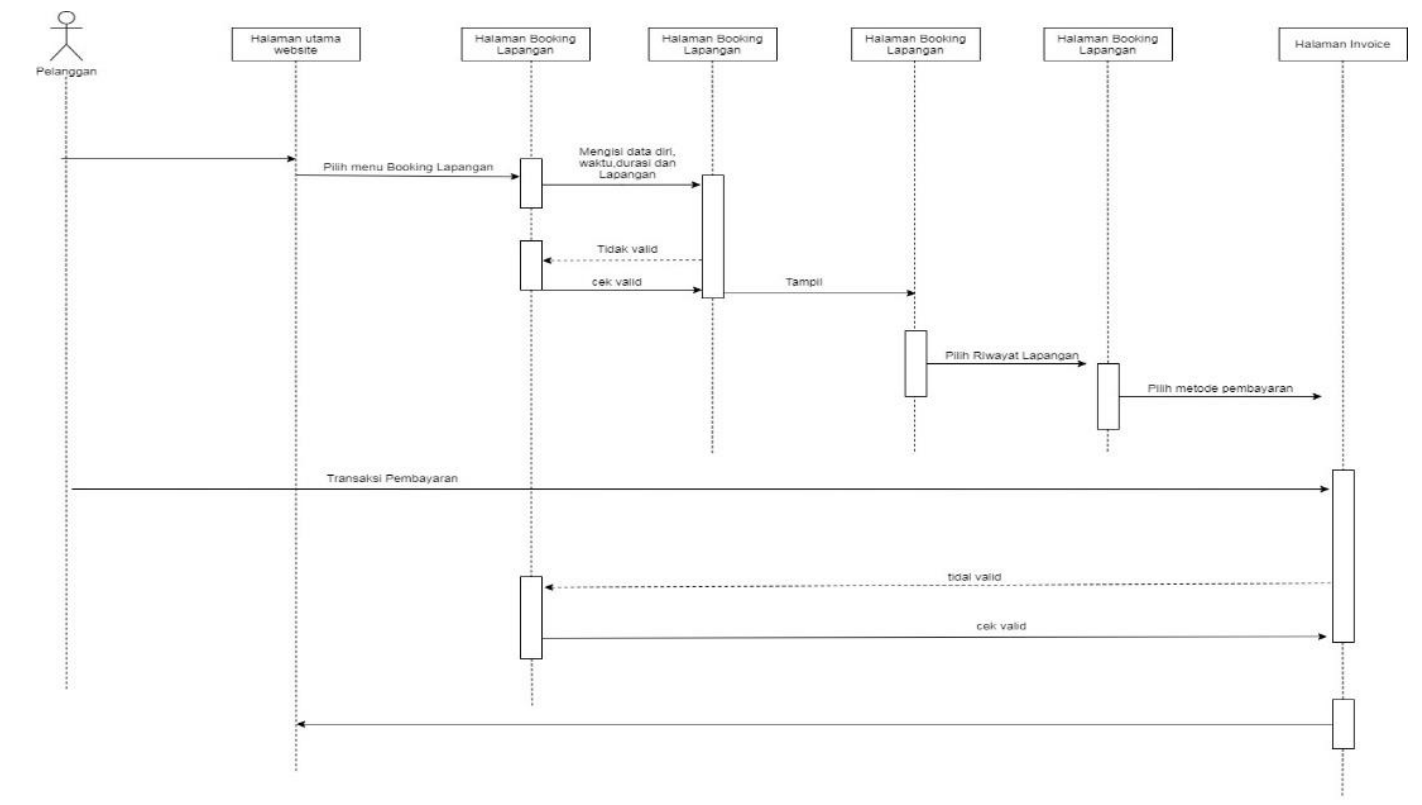

Sumber: Hasil Penelitian (2021)

Gambar 5. Sequence Diagram Pelanggan Booking 
Pelanggan melakukan Booking lapangan, seperti berikut (a) Pelanggan yang sudah masuk dalam Halaman Utama, (b) Lalu pelanggan memilih Booking Lapangan, (c) Pelanggan akan mengisi data diri, memilih waktu, durasi dan lapangan, (d) Proses verifikasi atau validasi cek ketersediaan data yang di isi pada database, (e) Database memverifikasi jika waktu, durasi dan lapangan tidak verifikasi salah akan kembali ke halaman Halaman Booking Lapangan, (f) Database akan memvalidasi apabila data yang dimasukkan pengguna telah cocok atau benar, (g) Maka akan tampil halaman data pelanggan sesuai yang di isi, (h) Lalu Pelanggan memilih Riwayat Lapangan, (i) Tampil Halaman Invoice, (j) Pelanggan akan memilih metode Pembayaran, (k) Pelanggan melakukan Pembayaran dengan Harga yang sudah ditentukan, (I) Proses verifikasi akan dilakukan Database, (m) Database memverifikasi jika Transaksi Pembayaran tidak verifikasi atau salah akan kembali ke halaman Halaman Booking Lapangan, (n) Database akan memvalidasi apabila Transaksi Pembayaran yang dimasukkan pengguna telah cocok atau benar, (o) Jika sudah melakukan Pembayaran dan Konfirmasi akan kembali ke Halaman Utama.

\subsection{Class Diagram}

Menggambarkan struktur dengan menunjukkan class, atribut, method, dan interaksi antara class dan objek berbagai komponen mewakili class yang akan diprogram.

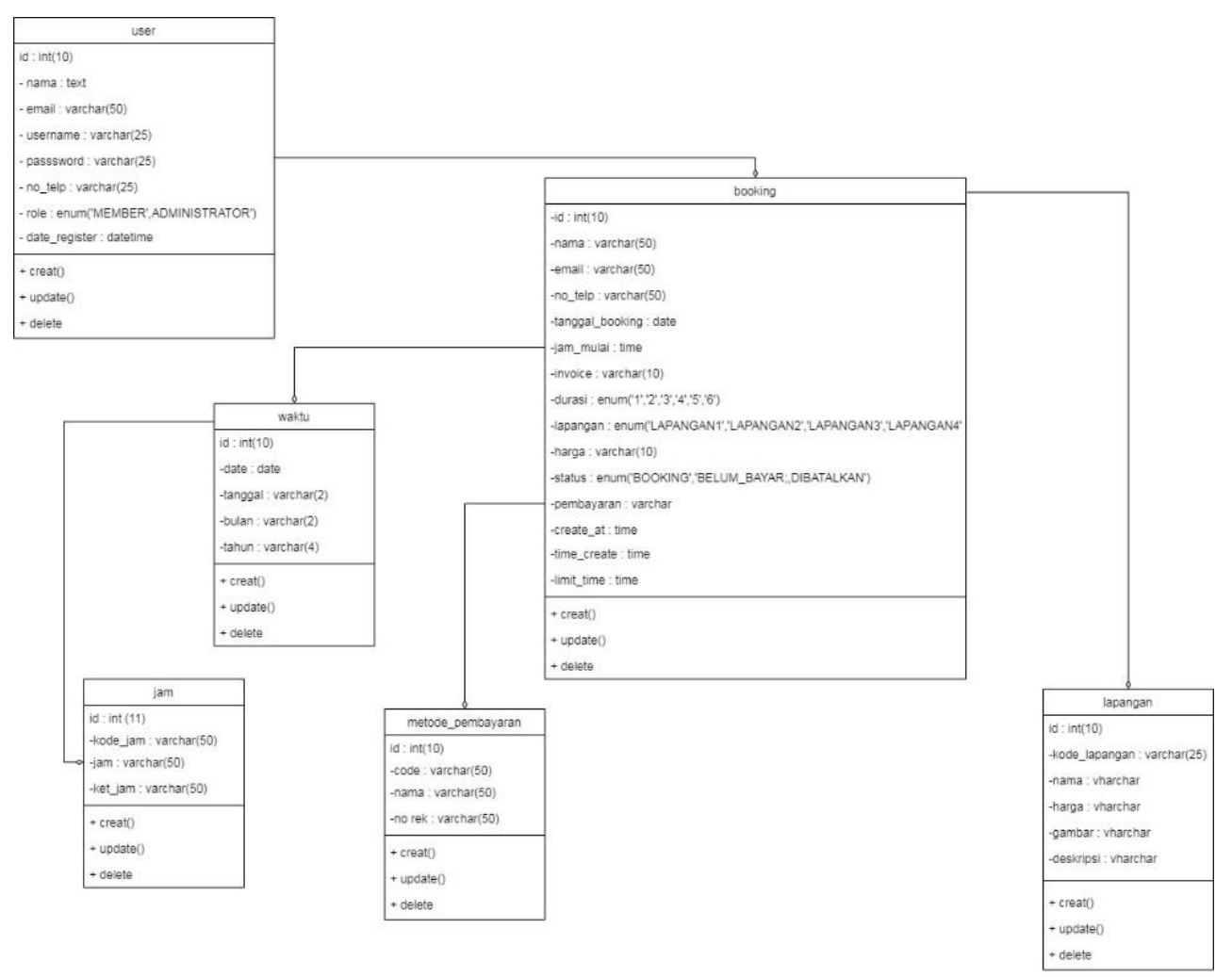

Sumber: Hasil Penelitian (2021)

\section{Gambar 6. Class Diagram}

\subsection{Implementasi User Interface}

Menjelaskan halaman pada sistem informasi penyewaan lapangan bulu tangkis GOR Villa Mas Indah Bekasi Utara. 


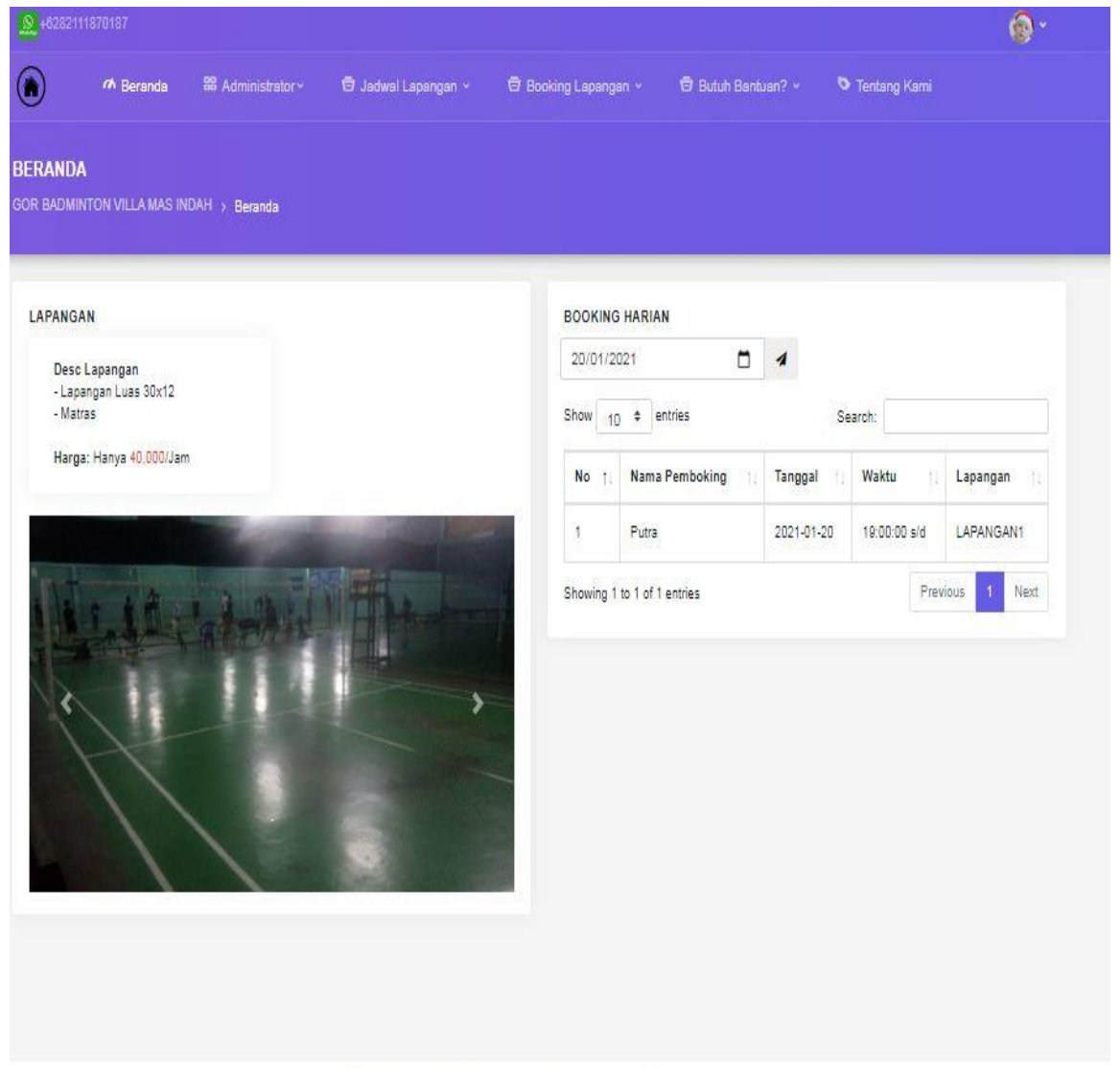

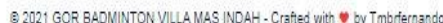

Sumber: Hasil Penelitian (2021)

\section{Gambar 7. Halaman Admin}

Pada gambar 7 halaman utama pengguna admin, halaman ini dapat diakses oleh admin, namun dalam halaman ini terdiri dari beberapa menu, menu admin terdiri dari lihat beranda, administrator yang didalamnya terdapat sub Menu Riwayat Booking, Kelola Booking, Metode Pembayaran dan User, Jadwal didalamnya ada sub Menu Lapangan 1, Lapangan 2, Lapangn 3 dan Lapangan 4, setelah Itu Menu Booking Lapangan terdiri sub Menu Booking dan Riwayat Booking, kemudian Menu Butuh Bantuan didalamnya Kontak Kami dan Faq dan terkahir Menu Tentang kami.

\section{Kesimpulan}

Berdasarkan hasil penelitian dan pembahasan yang telah dilakukan pada Sistem Informasi Penyewaan Lapangan Bulu Tangkis Berbasis Web Pada GOR Villa Mas Indah Bekasi Utara ini, maka dapat disimpulkan bahwa (a) Dengan adanya sistem informasi penyewaan lapangan bulu tangkis ini memudahkan pelanggan dalam melakukan penyewaan lapangan sesuai dengan waktu dan tanggal yang ditentukan, (b) Adanya website penyewaan lapangan ini diharapkan membantu pelanggan dalam menginformasikan jadwal yang tersedia, (c) Dengan adanya sistem informasi penyewaan lapangan bulu tangkis ini memudahkan pelanggan dalam melakukan pembayaran. 


\section{Daftar Pustaka}

Anggraeni, Elisabet Y. (2017). Pengantar Sistem Informasi. Andi.

Arief, M. F. (2019). Analisis dan Perancangan Sistem Informasi. Qiara Media.

Harianto, K., Pratiwi, H., \& Suhariyadi, Y. (2019). Sistem Monitoring Lulusan Perguruan Tinggi Dalam Memasuki Dunia Kerja Menggunakan Tracer Study. J-SAKTI (Jurnal Sains Komputer Dan Informatika), 3(2), 295. https://doi.org/10.30645/j-sakti.v3i2.148

Herlawati, Handayanto, R. T., \& Solikin. (2018). Neural network regression with support vector regression for land-use growth prediction. Proceedings of the 3rd International Conference on Informatics and Computing, ICIC 2018. https://doi.org/10.1109/IAC.2018.8780475

Hutahaen, J. (2015). Konsep Sistem Informasi. Deepublish.

Muslihudin, M., \& Oktafianto. (2016). Analisis dan Perancangan Sistem Informasi Menggunakan Model Terstruktur dan UML. Andi.

Mustaqbal, M. S., Firdaus, R. F., \& Rahmadi, H. (2015). Pengujian Aplikasi Menggunakan Black Box Testing Boundary Value Analisis (Studi Kasus : Aplikasi Prediksi Kelulusan SNMPTN). Jurnal Ilmiah Teknologi Informasi Terapan, I(3), 31-36.

Pressman, R. S., \& Maxim, B. M. (2015). Software Engineering A Practitioner's Approach. Mc Graw Hill Education.

Robi, A. (2020). Otodidak Web Programming: Membuat Website Edutainment. PT Elex Media Komputindo.

Sulisistiono, H. (2018). Coding Mudah dengan Codelgniter, JQuery, Bootstrap, dan Datatable. Elex Media Komputindo.

Yudhanto, Y., \& Prasetyo, H. A. (2018). Panduan Mudah Belajar Framework Laravel. Elex Media Komputindo. 